\title{
PENGARUH JOB INSECURITY, JOB SATISFACTION, DAN LINGKUNGAN KERJA TERHADAP TURNOVER INTENTION KARYAWAN
}

\author{
Novi Ali Marzuqi \\ Universitas Negeri Surabaya \\ na.marzuqi@gmail.com
}

Abstract

Turnover intention occurs when employees fail to get what they expect from their place of work, such as work satisfaction, comfort at the workplace, job future guarantee, etc. Employees who desire to resign from their company will start looking for job vacancies in other places that offer better opportunities than their current workplace. When they find a job vacancy that matches them, they will resign from their company. This research aimed to determine the impact of job insecurity, job satisfaction, and work environment on employee turnover intention. The research sample used was 80 outsourcing employees from PT Shelter Nusa Indah. The data analysis technique used in this study is the Multiple Linear Regression model using the IBM SPSS 23 program. The results of this study are that job insecurity has a positive and significant effect on turnover intention. Job satisfaction and work environment have a negative and significant impact on turnover intention. The managerial implications of this research are expected to be suggestions in making company policies related to turnover intention. The company is expected to reduce feelings of restlessness, anxiety and worry over the threats experienced by employees regarding their future in the company. The company is expected to give appreciation or reward to employees who have good performance and dedication to the company's progress. The company is expected to maintain and create a comfortable work environment for employees.

Keywords: job insecurity; job satisfaction; turnover intention; work environment

\section{PENDAHULUAN}

Virus Covid-19 menyebabkan krisis pada semua sektor bisnis di Indonesia. Hasil survei Badan Pusat Statistik (BPS) menunjukkan sebesar 82,85\% dari 34.559 perusahaan di Indonesia terdampak virus Covid-19. Berdasarkan bidang usahanya, diurutan pertama ada bisnis akomodasi dan bisnis makanan/minuman yang mengalami penurunan pendapatan sebesar 92,47\%. Kemudian bidang jasa sebesar $90,90 \%$ dan diikuti oleh usaha transportasi dan penyimpanan, konstruksi, manufaktur dan perdagangan (bps.go.id, 2020).

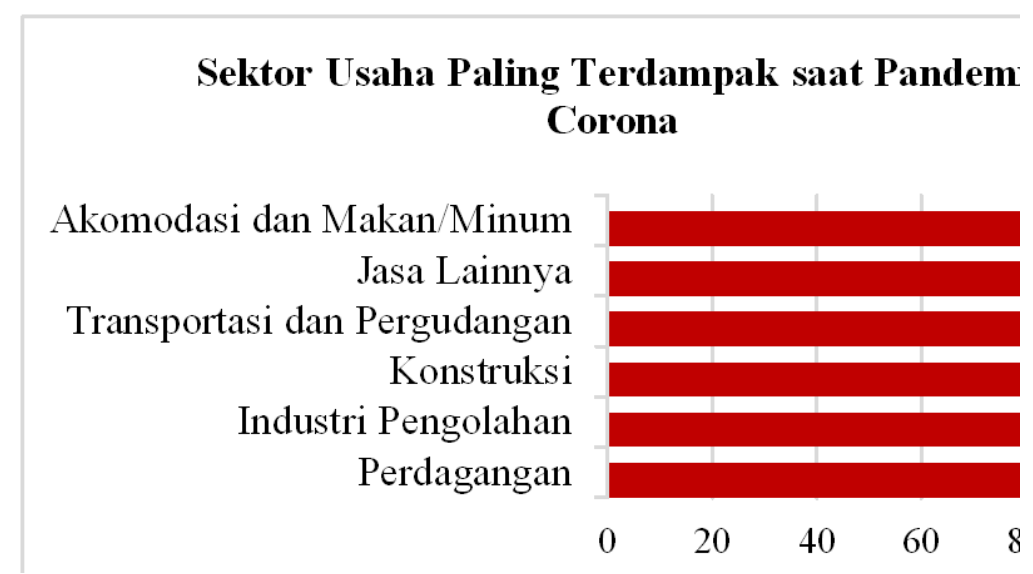

Sumber: bps.go.id (2020)

\section{Gambar 1. SEKTOR USAHA PALING TERDAMPAK SAAT PANDEMI CORONA}

Virus Covid-19 atau virus Corona sangat memengaruhi sektor ketenagakerjaan, khususnya sektor buruh. Setidaknya selama pandemi Covid-19 tahun 2020 ini, pekerja telah merasakan delapan dampak yang yaitu pekerja yang terpaksa terus bekerja seraya menghadapi risiko paparan Covid-19, kurangnya keamanan kerja, PHK besar-besaran, pemotongan gaji, bantuan sosial yang tidak tepat 
sasaran, pengusiran buruh migran yang tidak memiliki dokumen kerja di luar negeri, ekspoloitasi buruh perempuan baik secara kerja maupun seksual, dan banyaknya buruh yang masuk ke sektor informal (CNNIndonesia.com, 2020)

Sektor ketenagakerjaan Indonesia juga dihadapkan kebijakan baru, yaitu pemerintah melalui DPR RI pada tanggal 5 Oktober 2020 secara resmi mengumumkan penetapan UU No. 11 Tahun 2020 tentang Cipta Kerja atau UU Omnibus Law. Dengan berlakunya undang-undang tersebut, beberapa peraturan mengalami perubahan terkait sektor ketenagakerjaan di Indonesai. Namun, sebagian pembaruan regulasi itu menimbulkan resistensi dari serikat pekerja/serikat buruh di Indonesia. Beberapa perubahan tersebut berupa penghapusan pemberian uang pesangon, mudahnya akses masuk pekerja asing di Indonesia, penambahan jam kerja lembur dan penghapusan cuti panjang, dan dihapuskannya batasan maksimum 3 tahun bagi pekerja kontrak (CNNIndonesia.com, 2020). Menurut Kompas.com (2020), dihapuskannya aturan batas maksimal status pekerja kontrak, membuat perusahaan bebas mempekerjakan karyawan secara kontrak untuk waktu yang lama tanpa berkewajiban menjadikan mereka pekerja tetap. Selain itu, karyawan yang mengajukan pengunduran diri, meninggal dunia ataupun terkena PHK tidak akan mendapat haknya berupa uang pesangon dari perusahaan. Perusahaan juga tidak mendapat sanksi apabila memberikan upah dibawah ketentuan yang ditetapkan.

Beberapa ancaman yang diakibatkan adanya pandemi virus Covid-19, diberlakukkannya UU Ciptaker serta ancaman lain yang dialami pekerja, pada akhirnya dapat meyebabkan pekerja merasa khawatir tentang kepastian masa depan pekerjaannya (Lumbanrau, 2020). Perasaan khawatir, bingung, cemas, dan gelisah yang dialami oleh pekerja dikenal sebagai ketidakamanan kerja (Greenhalgh \& Rosenblatt, 1984)

Job Insecurity dikenal semenjak berbagai perusahaan memutuskan mempekerjakan karyawan secara kontrak akibat adanya perombakan perusahaan karena PHK, restrukturisasi organisasi dan penyatuan organisasi (Ashford et al., 1989). Greenhalgh \& Rosenblatt (1984) mendefinisikan job insecurity sebagai ketidakmampuan karyawan dalam menjaga kelangsungan pekerjaannya akibat adanya sesuatu yang mengancam pekerjaan mereka. Mauno et al. (2014) mengemukakan bahwa ada dua alasan yang menyebabkan ketidakamanan kerja yakni perubahan organisasi dan tekanan psikologis. Ketidakamanan kerja yang disebabkan oleh perubahan organisasi diantaranya seperti PHK, perampingan dan merger. Perubahan tersebut dapat memengaruhi kelompok tertentu dalam organisasi sehingga mendorong pemahaman mereka tentang ketidakamanan kerja. Sedangkan penyebab lainnya adalah tekanan psiokologis yang dialami karyawan seperti kelelahan dan semangat kerja karyawan yang rendah. Hal tersebut dapat berakibat terhadap kesehatan mental karyawan di tempat kerjanya, yang berkemungkinan dapat memunculkan keinginan karwayan untuk keluar dari perusahaan dan beralih ke pekerjaan lain (Greenhalgh \& Rosenblatt, 1984).

Menurut Koestanto \& Ardi (2017), keinginan berpindah merupakan indikasi awal terjadinya turnover di sebuah perusahaan. Karyawan yang memilik keinginan untuk berpindah pekerjaan, maka mereka akan sibuk mencari peluang pekerjaan di luar tempatnya bekerja. Jika karyawan telah mendapat kesempatan yang lebih baik, maka mereka akan memutuskan untuk keluar dari pekerjaannya saat ini. Turnover ialah kuputusan akhir atas semua sikap ketidakpuasan yang dirasakan oleh karyawan terhadap pekerjaan yang dilakukannya (Priansa, 2018). Audina \& Kusmayadi (2018) menyebutkan beberapa indikator pembentuk keinginan berpindah karyawan yaitu pikiran untuk meninggalkan perusahaan, pencarian informasi kesempatan bekerja di perusahaan lain, dan adanya niatan keluar dari perusahaan.

Terdapat sejumlah faktor yang dapat memengaruhi karyawan dalam memutuskan keluar dari tempat kerja, satunya ialah adanya faktor lingkungan kerja (Greenhalgh \& Rosenblatt, 1984). Menurut Halimah et al. (2016) Lingkungan kerja terbagi menjadi lingkungan fisik dan non-fisik. Lingkungan kerja fisik terkait dengan kondisi pencahayaan, cuaca, suhu udara, tata letak perusahaan, struktur gedung, dan lokasi kerja. Sedangkan lingkungan kerja non-fisik meliputi suatu hal yang berkenaan dengan interaksi sosial di sekitar lingkungan kerjanya dan kualitas kehidupan perusahaan. Saputra et al. (2020) mendefinisikan lingkungan kerja sebagai salah satu penyebab pekerja bisa menyelesaikan 
tugas dan pekerjaannya dengan baik. Dalam melakukan pekerjaannya, ada beberapa pekerja yang semangat dan ada yang kurang semangat. Suprayitno \& Sukir (2017) menjelaskan bahwa ketika karyawan kurang bersemangat dalam bekerja, hal tersebut dapat mengganggu mereka dalam menyelesaikan tugas yang diberikan. Demikian itu terjadi sebab pekerja tidak bisa mengerahkan pikiran dan tenaganya dengan semaksimal mungkin. Menurut Koestanto \& Ardi (2017), hubungan baik antar sesama rekan kerja dan interaksi karyawan dengan pimpinan juga dapat berpengaruh terhadap kenyamanan karyawan ketika bekerja. Dengan iklim kerja yang menyenangkan, eratnya hubungan antar sesama rekan kerja maupun dengan atasan, dapat membuat karyawan enggan berpikir untuk meninggalkan perusahaannya.

Faktor lain yang dapat menyebabkan turnover intention ialah kepuasan kerja (Kristanto et al. 2014). Kepuasan kerja ialah bagaimana respon karyawan tentang bekerja di suatu organisasi apakah mereka bahagia ataukah tidak. Kepuasan karyawan dalam bekerja merupakan hal yang bermanfaat dalam membentuk kematangan psikologis mereka (Rosmaini \& Tanjung, 2019). Pekerja yang tidak merasakan kepuasan dengan pekerjaannya, tidak akan memeroleh kematangan psikologis sehingga mengakibatkan perasaan depresi (Hanaysha \& Tahir, 2016). Kepuasan kerja memainkan peran penting terhadap keberhasilan organisasi, di mana kepuasan kerja yang tinggi akan mengurangi turnover intention dan dapat menaikkan semangat kerja karyawan (Dole \& Schroeder, 2001).

Kepuasan kerja memiliki pengaruh negatif terhadap turnover intention pekerja (Zhang et al., 2018). Artinya, ketidakpuasan karyawan di organisasi dapat menyebabkan turnover intention karyawan naik. Mbah \& Ikemefuna (2012) mengemukakan bahwa karyawan yang memeroleh kepuasan kerja akan membuat dirinya semakin termotivasi untuk semangat dalam bekerja dan dapat meningkatkan loyalitasnya terhadap perusahaan. Sebaliknya ketika karyawan tidak memeroleh kepuasan terhadap pekerjaannya, maka bisa menyebabkan karyawan memiliki niat untuk keluar dari perusahaan dan berpotensi pada kerugian perusahaan.

Penelitian dilakukan pada karyawan outsourcing PT Shelter Nusa Indah yang bekerja di PT Bayer Indonesia-Surabaya Plant. PT Shelter Nusa Indah ialah perusahaan yang bergerak di bidang jasa penyediaan/penyaluran tenaga kerja dan pemborongan pekerjaan. Berdiri tahun 2007 dan beralamatkan di Jl. Semampir Selatan V A No.18 Surabaya. Perusahaan ini telah melayani lebih dari 100 customer. Salah satu mitra PT Shelter Nusa Indah adalah PT Bayer Indonesia-Surabaya Plant. Perusahaan ini memproduksi dan memasarkan komoditas perlindungan dan pengatur tumbuh tanaman seperti insektisida, fungisida heribisida dan pestisida pelindung tumbuhan. Perusahaan ini beralamatkan di Jl. Rungkut Industri 1 No 12 Surabaya. Berdasarkan observasi dan wawancara yang telah dilakukan dengan Relation Officer PT Shelter Nusa Indah, Bapak Yofi Firmansyah, perusahaan ini terjadi peningkatan turnover karyawan. Hasil wawancara diketahui penyebab keluarnya karyawan dari perusahaan diantaranya seperti kepuasan mengenai gaji. Karyawan mengalami pemotongan gaji akibat adanya pandemi virus Covid-19. Sehingga karyawan mengalami kesulitan dalam memenuhi kebutuhan kehidupannya. Ada karyawan yang keluar dari perusahaan dikarenakan ingin mengembangkan usaha yang dirintisnya. Hubungan antar karyawan yang kurang erat menimbulkan perasaan cemas, was-was dan kegelisahan ketika bekerja. Tekanan yang tinggi dari perusahaan menimbulkan perasaan tidak nyaman bagi karyawan. Sehingga karyawan terkadang berpikir ingin meninggalkan pekerjaannya dan bekerja di perusahaan lain. Berdasarkan uraian di atas, tujuan penelitian ini untuk mengetahui pengaruh job insecurity, job satisfaction dan lingkungan kerja terhadap turnover intention karyawan outsourcing.

\section{KAJIAN PUSTAKA DAN PENGEMBANGAN HIPOTESIS}

\section{Turnover Intention}

Mobley (2011) mendefinisikan turnover intention sebagai keinginan karyawan untuk mengundurkan diri dari pekerjaan mereka atau berganti dari perusahaan lama ke perusahaan baru atas kehendak diri sendiri. Akgunduz \& Eryilmaz (2018) berpandangan bahwa turnover intention karyawan merujuk pada kesadaran atau pemikiran tentang keluar dari perusahaannya saat ini. Sebelum memutuskan 
keluar dari tempat kerjanya, pekerja yang berniat keluar dari pekerjaannya, maka mereka mulai mencari informasi lowongan pekerjaan di perusahaan lain (Kartika \& Purba, 2018). Turnover intention merupakan sinyal awal untuk pergantian karyawan dan didefinisikan sebagai penarikan individu dari pekerjaan atau organisasi mereka, dan secara aktif mencari pekerjaan lain atau alternatif karir (Haque et al., 2019). Turnover adalah kuputusan akhir atas semua sikap ketidakpuasan yang dirasakan oleh karyawan terhadap pekerjaan yang dilakukannya (Priansa, 2018). Oleh sebab itu diperlukan upaya untuk menekan tingginya turnover intention karyawan dalam waktu tertentu (Parwita et al., 2019). Indikator turnover intention menurut Audina \& Kusmayadi (2018) meliputi pikiran untuk meninggalkan perusahaan, pencarian informasi terkait kesempatan bekerja di perusahaan lain, dan niatan keluar dari perusahaan.

\section{Job Insecurity}

Menurut Greenhalgh \& Rosenblatt (1984) job insecurity sebagai ketidakmampuan karyawan dalam menjaga kelangsungan pekerjaannya akibat adanya sesuatu yang mengancam pekerjaan mereka. Apabila karyawan menghadapi tekanan yang besar di tempat kerja, dapat memunculkan keinginan karwayan berhenti bekerja dan beralih ke tampat lain. Hellgren et al. (1999) membagi job insecurity menjadi dua dimensi yakni quantitative job insecurity dan qualitative job insecurity. Quantitative job insecurity ialah kekhawatiran karyawan atas ancaman kehilangan pekerjaan mereka saat ini. Sedangkan qualitative job insecurity berhubungan atas penurunan kualitas dalam hubungan kerja, seperti buruknya lingkungan kerja, minimnya promosi, dan pemotongan upah. Persepsi ketidakamanan kerja bisa dimaknai sebagai kegelisahan karyawan atas kemungkinan hilangnya pekerjaan mereka saat ini serta kecemasan menjadi pengangguran (De Witte, 1999). Ketidakamanan kerja juga merupakan salah satu penyebab menurunnya antusiasme karyawan dalam bekerja (Ünsal et al., 2012). Pengukuran variabel job insecurity mengacu pada penelitian (Jung et al., 2021) dengan menggunakan skala Likert lima poin.

\section{Job Satisfaction}

Kreitner \& Angelo (2014) mengemukakan bahwa kepuasan kerja didefinisikan sebagai reaksi emosional individu terkait aspek pekerjaannya. Kepuasan karyawan memainkan peran penting terhadap keberhasilan organisasi, di mana kepuasan karyawan yang tinggi akan mengurangi tingkat pergantian karyawan dan dapat menaikkan semangat kerja karyawan (Dole \& Schroeder, 2001). Kepuasan karyawan juga dapat meningkatkan produktivitas karyawan. Seseorang yang tidak puas terhadap pekerjaannya, maka mereka tidak pernah memeroleh kematangan psikologis, yang akibatnya dapat menyebabkan perasaan depresi (Hanaysha \& Tahir, 2016). Edison et al. (2018) mengartikan kepuasan kerja sebagai serangkaian perasaan yang dimiliki oleh karyawan terhadap pekerjaan yang mereka kerjakan, baik itu menyenangkan ataupun tidak menyenangkan. Menurut Sutrisno (2016) terdapat empat aspek penyebab kepuasan kerja yakni sebagai berikut. (1) Aspek psikologis yang berkaitan dengan psikologis atau kejiwaan karyawan seperti antusias karyawan dalam bekerja, kenyamnan dalam bekerja. (2) Aspek sosial yang berkenaan dengan interaksi sosial antar pekerja, maupun bawahan terhadap atasan. (3) Aspek fisik yang berkaitan dengan keadaan fisik pekerja dan keadaan lingkungan kerja fisik di sekitar pekerja. (4) Aspek finansial yang berkaitan dengan kesejahteraan dan jaminan yang didapat pekerja. Indikator pembentuk kepuasan kerja menurut Widodo (2015) yakni pekerjaan itu sendiri, gaji, partner kerja, pengembangan karier, serta atasan.

\section{Lingkungan Kerja}

Lingkungan kerja ialah suatu hal yang berada di sekeliling pekerja, di mana akan memberikan dampak dalam menjalankan pekerjaannya, diantaranya berupa temperatur, kelembaban, sirkulasi udara, pencahayaan, suara bising, kebersihan, dan kelengkapan alat kerja (Afandi, 2018). Lingkungan kerja menjadi salah satu faktor yang memengaruhi pekerja dalam menyelesaikan tugas dan pekerjaannya dengan baik (Saputra et al., 2020). Kenyamanan yang didapatkan ketika bekerja bisa mendorong performa maksimal seorang pegawai seperti yang diharapkan oleh perusahaan. Di sisi lain, lingkungan kerja yang tidak nyaman dapat menurunkan kinerja mereka (Putri et al., 2019). Fahmy et al. (2021) mengungkapkan lingkungan kerja sebagai apa saja yang berada di sekeliling karyawan yang dapat memengaruhi mereka dan pekerjaannya, baik itu berupa aspek fisik maupun aspek non fisik. Siagian \& Khair (2018) menyatakan lingkungan kerja sebagai ruang di mana 
karyawan menjalankan rutinitas tugas dan pekerjaannya dengan baik. Lingkungan kerja yang kondusif mampu menaikkan semangat pegawai disaat mengerjakan tugas dari perusahaan. Namun ketika lingkungan kerja tidak menyenangkan, karyawan cenderung tidak bersemangat dalam melakukan pekerjaannya, yang berdampak negatif terhadap kinerja. Oleh karena itu penting bagi perusahan untuk mewujudkan kenyamanan dan keamanan bagi karyawan mereka. Dengan terciptanya lingkungan yang kondusif, maka kinerja karyawan bisa meningkat dan dapat mencapai tujuan perusahaan. Sedarmayanti (2017) menyebutkan bahwa variabel lingkungan kerja disusun atas beberapa indikator pengukuran yaitu: pencahayaan, temperatur udara, kebisingan, keamanan kerja dan interaksi sosial pekerja.

\section{Hubungan antar Variabel}

Greenhalgh \& Rosenblatt (1984) mengartikan job insecurity sebagai ketidakmampuan karyawan dalam menjaga kelangsungan pekerjaannya akibat adanya sesuatu yang mengancam pekerjaan mereka. Jika karyawan menghadapi ancaman yang besar di tempat kerjanya, hal itu dapat memunculkan keinginan karwayan meninggalkan tempat kerjanya saat ini kemudian beralih ke perusahaan lain. Pengaruh job insecurity terhadap keinginan berpindah karyawan ini telah banyak dipelajari oleh beberapa peneliti terdahulu. Saputra et al. (2020), Januartha \& Adnyani (2019), Koestanto \& Ardi (2017) menyatakan bertambahnya job insecurity yang dialami pekerja maka intensi turnover juga akan meningkat. Hal itu mempunyai makna bahwa job insecurity memilik pengaruh positif dan signifikan dengan niat untuk pindah kerja. Lee \& Jeong (2017) juga berpendapat bahwa job insecurity berkaitan secara signifikan dengan turnover intention. Pendapat tersebut diperkuat oleh Arnold \& Feldman (1982) yang menyatakan bahwa ketidakamanan kerja merupakan penyebab potensial dari meningkatnya niat keluar dari karyawan. Akgunduz \& Eryilmaz (2018), berpendapat bahwa diperlukan upaya untuk mengurangi persepsi job insecurity untuk mencegah hilangnya personel yang sangat baik. Berdasarkan pernyataan di atas dapat diuraikan hipotesis berikut ini.

\section{H1: Job insecurity berpengaruh positif terhadap turnover intention karyawan.}

Kepuasan kerja menggambarkan seberapa besar seseorang senang terhadap pekerjaan mereka. Job satisfaction bisa diartikan tanggapan emosional seseorang terkait aspek pekerjaannya (Kreitner \& Angelo, 2014). Kepuasan kerja bepengaruh secara negatif terhadap keinginan karyawan untuk pindah, yang artinya ketidakpuasan kerja dapat menyebabkan keinginan pindah karyawan semakin tinggi dan sebaliknya, jika kepuasan karyawan tinggi maka tingkat keinginan karyawan untuk berpindah semakin menurun (Mbah \& Ikemefuna, 2012). Beberapa penelitian yang juga mendukung Ikemefuna et al. (2012) adalah penelitian Halimah et al. (2016), Putra \& Utama (2017), Koestanto \& Ardi (2017), dan Zhang et al. (2018).

\section{H2: Job satisfaction berpengaruh negatif terhadap turnover intention karyawan.}

Afandi (2018) mengartikan lingkungan kerja sebagai suatu yang berada di sekeliling pekerja, di mana akan memberikan dampak pada mereka dalam menjalankan pekerjaannya, diantaranya berupa temperatur, kelembaban, sirkulasi udara, pencahayaan, suara bising, kebersihan, dan kelengkapan alat kerja. Lingkungan kerja banyak dikaitkan berpengaruh negatif dengan turnover intention karyawan. Menurut Quareshi (2012) lingkungan kerja berpengaruh negatif terhadap turnover intention, artinya kenyamanan dalam bekerja mampu menurunkan tingkat turnover intention karyawan. Beberapa studi yang juga mendukung hasil penelitian tersebut adalah Koestanto \& Ardi (2017), Putri \& Irfani (2020), Nikmah et al. (2018), serta Saputra et al. (2020).

H3: Lingkungan kerja berpengaruh negatif terhadap turnover intention karyawan.

\section{METODE PENELITIAN}

Penelitian yang digunakan adalah penelitian kuantitatif dengan menggunakan pendekatan asosiatif yang tujuannya untuk menganalisis pengaruh variabel bebas job insecurity, job satisfaction dan 
lingkungan kerja terhadap variabel terikat turnover intention. Ukuran sampel yang digunakan berjumlah 80 (delapan puluh) orang dengan menggunakan teknik non-probability sampling jenis purposive sampling. Responden merupakan karyawan outsourcing PT. Shelter Nusa Indah yang bekerja di bagian produksi dan berusia antara 20-40 tahun dan telah bekerja selama 1 tahun di mana pada usia tersebut karyawan masih memiliki kecenderungan untuk berpindah kerja. Karyawan yang telah bekerja 1 tahun, lebih mengetahui tentang kondisi pekerjaannya.

Penelitian menggunakan Regresi Linier Berganda dengan program IBM SPSS 23. Instrumen pengambilan data penelitian menggunakan observasi, wawancara dan kuesioner atau angket. Kuesioner terdiri dari beberapa item pernyataan yang merupakan indikator penyusun masing-masing variabel penelitian. Daftar item pernyataan tersebut kemudian diserahkan pada responden dengan maksud agar responden memberikan tanggapannya sesuai yang dialaminya. Penelitian ini menggunakan skala Likert 5 poin yaitu $1=$ sangat tidak setuju, $2=$ tidak setuju, $3=$ netral, $4=$ setuju, $5=$ sangat setuju. Hasil pengambilan data di analisis menggunakan uji validitas dan reliabilitas untuk mengetahui seberapa tepat/benar dan konsisten alat ukur dalam pengukuran. Selanjutnya peneliti mengaplikasikan uji asumsi klasik diantaranya seperti uji normalitas, uji heterkedastisitas, dan uji multikolinearitas. Langkah terakhir dengan uji analisis regresi linear berganda.

\section{HASIL DAN PEMBAHASAN}

\section{Karakteristik Responden}

Semua responden dalam studi ini adalah laki-laki dengan jumlah 80 orang. Hal tersebut karena pekerjaan yang dilakukan tergolong berat dan beresiko terkena cairan kimia. Responden merupakan karyawan dengan pendidikan terakhir SLTA atau sederajat. Berdasarkan tingkat usia responden, sebanyak 20 orang (25\%) berumur 20-26 tahun. Sejumlah 34 orang (42\%) berumur 27-33 tahun. Sebanyak 26 orang (33\%) berumur 34-40 tahun. Berdasarkan lama bekerja responden, sebanyak 30 orang (37\%) memiliki masa kerja 1-2 tahun. Sejumlah 40 orang (50\%) telah bekerja selama 3-4 tahun. Serta sebanyak 10 orang (13\%) telah bekerja selama $>4$ tahun.

\section{Uji Validitas dan Reliabilitas}

Berdasarkan hasil uji validitas, nilai $\mathrm{r}$ hitung (Pearson Correlation) semua item penyataan dari variabel penelitian yang digunakan, bernilai lebih besar daripada $r$ tabel $(0,220)$ yakni antara 0,449 sampai dengan 0,896. Dengan hal itu, semua item pernyataan dalam variabel penelitian dapat dikatakan valid dikarenaka nilai $r_{\text {hitung }}>r_{\text {tabel }}$ oleh karenanya semua item penyataan bisa dipakai guna menguji setiap variabel penelitian. Sedangkan berdasarkan hasil uji reliabilitas, nilai Cronbach's Alpha pada setiap variabel yaitu job insecurity sebesar 0,846 , job satisfaction senilai 0,640, lingkungan kerja senilai 0,789, dan turnover intention senilai 0,860. Nilai Cronbach's Alpha dari masing-masing variabel penelitian lebih besar atau sama dengan 0.6. Oleh karenanya semua butir pernyataan pada penelitian ini dapat dinyatakan reliabel atau teruji. Hal tersebut sesuai dengan pendapat Sujarweni (2015) kuesioner atau angket dinyatakan reliabel atau konsisten andaikan nilai Cronbach's Alpha lebih besar atau sama dengan 0,60

\section{Uji Normalitas}

Berdasarkan Kolmogorov-Smirnov Test menggunakan program IBM SPSS 23 diperoleh angka Asymp. Sig (2-tailed) lebih dari batas signifikan yang ditetapkan $(0,05)$, yakni sebesar 0,073 >0,05. Oleh karena itu bisa dinyatakan bahwa persebaran data penelitian ini bersifat normal.

\section{Uji Heterokedastisitas}

Tabel 1 menunjukkan nilai signifikansi dari setiap variabel bebas dalam penelitian ini melebihi 0,05. Variabel job insecurity $(0,636)$, job satisfaction $(0,815)$, dan lingkungan kerja $(0,492)$. Dengan demikian dinyatakan bahwa tidak ditemukan indikasi heteroskedastisitas pada model regresi ini. 


\section{Tabel 1. UJI HETEROKEDASTISITAS}

\begin{tabular}{ccc}
\hline Model & T & Sig. \\
\hline (Constant) & .552 & .603 \\
Job Insecurity & .475 & .636 \\
Job Satisfaction & -.192 & .815 \\
Lingkungan Kerja & -.547 & .492 \\
\hline
\end{tabular}

Sumber: Data diolah (2021)

\section{Uji Multikolinearitas}

Berdasarkan hasil uji multikolinearitas diperoleh nilai tolerance dan VIF (Variance Inflaction Factor) dari masing-masing variabel penelitian, yaitu variabel job insecurity sebesar 0,345 dengan VIF 2,898, variabel job satisfaction 0,315 dengan VIF 3,180, dan variabel lingkungan kerja sebesar 0,808 dengan VIF 1,238. Nilai tolerance dan VIF dari ketiga varibel penelitian ini $>0,1$ dan $<10$, dengan demikian dapat antara variabel bebas tidak mengalami gejala multikolinearitas.

\section{Analisis Regresi Linear Berganda}

Tabel 2.

ANALISIS REGRESI LINEAR BERGANDA

\begin{tabular}{llccccc}
\hline \multirow{2}{*}{ Model } & \multicolumn{2}{c}{$\begin{array}{c}\text { Unstandardized } \\
\text { Coefficients }\end{array}$} & \multicolumn{2}{c}{$\begin{array}{c}\text { Standardized } \\
\text { Coefficients }\end{array}$} & & \\
\cline { 3 - 5 } & & $\mathbf{B}$ & Std. Error & Beta & t & Sig. \\
\hline 1 & (Constant) & 41.954 & 4.627 & & 9.067 & .000 \\
& Job Insecurity & .492 & .206 & .392 & 2.392 & .019 \\
& Job Satisfaction & -.839 & .300 & -.480 & -2.796 & .007 \\
& Lingkungan Kerja & -.545 & .171 & -.342 & -3.188 & .002 \\
\hline
\end{tabular}

Sumber: Data diolah (2021)

Sesuai hasil analisis regresi linear berganda pada tabel 2, selanjutnya dirumuskan persamaan regresi pada persamaan (1). Koefisien regresi variabel job insecurity memiliki nilai 0,363. Maksudnya tiap kenaikan satu satuan pada job insecurity, akan diikuti penurunan pada turnover intention sebesar $(0,492)$. Job satisfaction $(-0,839)$ maksudnya tiap kenaikan satu satuan pada job satisfaction akan diikuti penurunan tingkat turnover intention sebanyak $(-0,839)$. Lingkungan kerja $(-0,545)$ maksudnya tiap peningkatan satu satuan pada lingkungan kerja akan terjadi penurunan sebanyak $(-0,545)$ pada turnover intention.

$\mathrm{Y}=41,954-0,492 \mathrm{X}_{1}-0,839 \mathrm{X}_{2}-0,545 \mathrm{X}_{3}$

\section{Hasil Uji t}

Berdasarkan tabel 2 ditemukan nilai t hitung job insecurity (X1) senilai 2,392 lebih tinggi daripada $t$ tabel $(1,668)$. Dengan nilai signifikan lebih kecil daripada 0,05 yaitu sebesar 0,019. Dapat diartikan bahwa variabel job insecurity berpengaruh signifikan terhadap turnover intention. Variabel job satisfaction (X2) memperoleh skor t hitung sebesar -2,796 dan signifikansi 0,007. Artinya job satisfaction memiliki pengaruh atas turnover intention secara signifikan. Variabel lingkungan kerja (X3) memeroleh skor $t$ hitung senilai $-3,188$ dengan nilai signifikan sejumlah 0,002 . Artinya lingkungan kerja memiliki pengaruh signifikan atas turnover intention.

\section{Hasil Uji F}

Berdasarkan hasil penelitian, ditemukan nilai $\mathrm{F}$ hitung sebesar 10,630 dengan angka signifikansinya 0,000 . Nilai $F$ hitung melebihi nilai $F$ tabel 2,720 dan angka probabilitasnya kurang dari 0,05 . Dengan 
Novi Ali Marzuqi. Pengaruh Job Insecurity, Job Satisfaction, Dan Lingkungan Kerja Terhadap Turnover Intention Karyawan.

demikian, dapat diartikan bahwa variabel dependen dipengaruhi oleh keseluruhan variabel independen.

Tabel 3.

HASIL UJI F

\begin{tabular}{llrrrrr}
\hline Model & & Sum Of Squares & Df & Mean Square & F & \multicolumn{1}{c}{ Sig. } \\
\hline 1 & Regression & 278.856 & 3 & 151.130 & 10.630 & $.000^{\mathrm{b}}$ \\
& Residual & 784.831 & 76 & 14.217 & & \\
& Total & 1063.688 & 79 & & & \\
\hline
\end{tabular}

Sumber: Data diolah (2021)

\section{Pengaruh Job Insecurity terhadap Turnover Intention}

Berdasarkan uji hipotesis, diketahui bahwa variabel job insecurity berpengaruh positif dan signifikan terhadap turnover intention karyawan. Hal ini menunjukkan apabila job insecurity yang dialami karyawan meningkat maka akan diikuti peningkatan pada intensitas turnover karyawan. Berdasarkan pengamatan dan hasil jawaban responden yang diperoleh, ditemukan bahwa pekerja terkadang merasa gelisah, tidak yakin dengan masa depannya di perusahaan karena keadaan lingkungan yang terus berubah-ubah. Karyawan merasa takut apabila dengan kehilangan pekerjaannya maka dapat menurunkan harga dirinya di masyarakat. Pemberhentian karyawan atau pemangkasan gaji dapat dilakukan sewaktu-waktu apabila perusahaan mengalami kesulitan. Hal tesebut menimbulkan kecemasan dan kekhawatiran bagi karyawan akan kesejahteraan mereka, yang pada akhirnya dapat memunculkan keinginan karyawan untuk keluar dari perusahaan.

Hasil tersebut mendukung penelitian Greenhalgh \& Rosenblatt (1984) bahwa terdapat hubungan positif antara job insecurity dengan turnover intention. Apabila karyawan menghadapi tekanan yang besar di tempat kerjanya, hal itu dapat memunculkan keinginan karwayan berhenti dari tempat kerja mereka dan beralih ke tampat lain. Hasil pengujian ini selaras dengan penelitian Saputra et al.,(2020), Januartha \& Andyani (2019), Koestanto \& Ardi (2017) dan Penyataan tersebut diperkuat oleh pendapat Mobley (2011) yang menyatakan bahwa fenomena turnover selalu diawali dengan munculnya keinginan untuk berhenti bekerja dari tempatnya saat ini.

\section{Pengaruh Job Satisfaction terhadap Turnover Intention}

Berdasarkan hasil uji hipotesis, ditemukan bahwa job satisfaction berpengaruh negatif dan signifikan terhadap turnover intention. Sehingga, apabila kepuasan kerja karyawan rendah, pikiran untuk berhenti dari pekerjaanya semakin meningkat. Sebaliknya, ketika kepuasan kerja tinggi, keinginan karyawan untuk meninggalkan perusahaannya semakin rendah. Berdasarkan hasil wawancara dengan karyawan, beberapa pekerja jarang mendapatkan kesempatan pengembangan karier dari perusahaan. Sebagian karyawan menilai perusahaan belum begitu transparan mengenai nilai atau standar yang harus dicapai karyawan agar mendapat promosi. Karyawan kurang puas dengan kebijakan baru perusahaan yakni terkait pemotongan upah karyawan akibat adanya Covid-19. Dengan pemotongan tersebut, karyawan merasa semakin kesulitan memenuhi kebutuhan diri mereka. Selain itu, berdasarkan jawaban kuesioner responden, ditemukan bahwa hubungan antar sesama karyawan belum terjalin erat sehingga terkadang menimbulkan perasaan tidak nyaman dalam bekerja. Hasil tesrsebut diperkuat oleh pernyataan Bapak Yofi selaku Relation Officer PT Shelter Nusa Indah yang mengungkapkan bahwa beberapa tahun terakhir perusahaan tidak mengadakan acara keakraban antar karyawan.

Hasil pengujian hipotesis ini mendukung pendapat Mbah \& Ikemefuna (2012) yang menyatakan bahwa ketidakpuasan kerja dapat menyebabkan keinginan pindah karyawan semakin tinggi dan sebaliknya, jika kepuasan karyawan tinggi maka tingkat keinginan karyawan untuk berpindah semakin menurun. Penelitian ini juga sejalan dengan penelitian Tripath \& Pandey (2017), Zhang et al., (2018), Prabawa \& Suwandana (2017), Halimah et al., (2016) Utama \& Surya (2020), Hal ini diperkuat oleh pendapat Dole \& Schroeder (2001) Kepuasan karyawan memainkan peran penting 
terhadap keberhasilan organisasi, di mana kepuasan karyawan yang tinggi akan mengurangi tingkat pergantian karyawan dan dapat menaikkan semangat kerja karyawan.

\section{Pengaruh Lingkungan Kerja terhadap Turnover Intention}

Berdasarkan pengujian hipotesis, ditemukan bahwa variabel lingkungan kerja berpengaruh negatif dan signifikan terhadap niat karyawan dalam meninggalkan perusahaan. Sehingga ketika lingkungan kerja tidak baik atau kurang kondusif maka bisa menaikkan pikiran karyawan untuk berhenti bekerja dari perusahaan mereka. Berdasarkan hasil jawaban responden, karyawan setuju bahwa mereka akan nyaman untuk terus bekerja apabila kondisi udara perusahaan berjalan baik, tidak lembab dan tidak kering, pencahayaan yang cukup, kemudian tidak terganggu oleh suara bising mesin produksi, dan tersedia peralatan keamanan yang memadai serta adanya pihak keamanan yang menjamin rasa aman karyawan selama bekerja di perusahaan.

Pengujian hipotesis ini mendukukung hasil penelitan Quareshi (2012) bahwa lingkungan kerja memiliki pengaruh negatif terhadap niat berpindah kerja. Hal ini diperkuat pendapat Joarder et al (2011), dengan terciptanya kenyamanan lingkungan kerja, semisal pencahayaan yang mencukupi serta adanya perasaan aman dari tindak kriminalitas maka dapat menurunkan kenginan untuk berhenti dari tempat kerjanya saat ini. Penelitian ini selaras dengan hasil studi terdahulu oleh Koestanto \& Ardi (2017), Intan \& Irfani (2020), Nikmah et al. (2018), Saputra et al. (2020).

\section{KESIMPULAN}

Berdasarkan hasil pengujian hipotesis yang telah dilakukan membuktikan bahwa secara positif job insecurity memengaruhi turnover intention karyawan PT. Shelter Nusa Indah. Artinya ketika ancaman yang dialami pekerja itu tinggi, maka dapat meningkatkan intensi turnover karyawan. Job satisfaction memiliki pengaruh negatif dan signifikan terhadap turnover intention karyawan PT. Shelter Nusa Indah, artinya semakin rendahnya tingkat kepuasan kerja maka keinginan karyawan untuk berhenti bekerja semakin tinggi. Lingkungan kerja memiliki pengaruh negatif dan signifikan terhadap turnover intention karyawan PT Shelter Nusa Indah, artinya ketika lingkungan kerja karyawan sudah baik atau kondusif maka akan menurunkan keinginan mereka untuk meninggalkan perusahaan.

Implikasi manajerial pada penelitian ini, perusahaan diharapkan bisa mengurangi perasaan gelisah, cemas dan kekhawatiran atas ancaman yang dialami karyawan mengenai masa depannya di perusahaan, salah satunya yaitu memberikan bimbingan konseling untuk mengelola stress atau tekanan psikologis yang dialami karyawan. Perusahaan diharapkan memberikan apresiasi atau reward kepada karyawan yang memiliki kinerja dan dedikasi yang baik terhadap kemajuan perusahaan. Misalnya dengan memberikan pujian maupun kesempatan promosi. Perusahaan diharapkan bisa memelihara dan mewujudkan lingkungan kerja yang nyaman bagi karyawan bukan hanya secara fisik namun juga sosial. Penelitian ini terbatas dilakukan terhadap karyawan outsourcing yang bekerja di bagian produksi. Penelitian selanjutnya diharapkan dapat menggunakan variabel berbeda yang berkaitan dengan turnover intention seperti work-family conflict, work engagement, sosial media atau variabel lainnya, ataupun menggunakan metode analisis lainnya sehingga hasil penelitian terkait turnover intention lebih bervariasi dan lebih akurat.

\section{DAFTAR PUSTAKA}

Afandi, P. (2018). Manajemen Sumber Daya Manusia ( Teori, Konsep dan Indikator). Riau: Zanafa Publishing.

Akgunduz, Y., \& Eryilmaz, G. (2018). Does Turnover Intention Mediate the Effects of Job Insecurity And Co-Worker Support on Social Loafing? International Journal of Hospitality Management, 68, 41-49. https://doi.org/10.1016/j.ijhm.2017.09.010

Arnold, H. J., \& Feldman, D. C. (1982). A Multivariate Analysis of The Determinants of Job 
Novi Ali Marzuqi. Pengaruh Job Insecurity, Job Satisfaction, Dan Lingkungan Kerja Terhadap Turnover Intention Karyawan.

Turnover. Journal of Applied Psychology, 67(3), 350-360. https://doi.org/10.1037//00219010.67.3.350

Ashford, S. J., Lee, C., \& Bobko, P. (1989). Content, Cause, and Consequences of Job Insecurity: A Theory-Based Measure and Substantive Test. Academy of Management Journal, 32(4), 803829. https://doi.org/10.5465/256569

Audina, V., \& Kusmayadi, T. (2018). Pengaruh Job Insecurity dan Job Stress terhadap Turnover Intention (Studi Pada Staff Industri Farmasi Lucas Group Bandung). Sains Manajemen \& Akuntansi, X(1), 85-101. http://ojs.stan-im.ac.id/index.php/JSMA/article/view/29

Bps.go.id. (2020). Analsis Hasil Survei Dampak Covid-19 Terhadap Pelaku Usaha. Analisis Hasil Survei Dampak COVID-19 terhadap Pelaku usaha. Retrieved October 18, 2021, from https://www.bps.go.id/publication/2020/09/15/9efe2fbda7d674c09ffd0978/analisis-hasil-surveidampak-covid-19-terhadap-pelaku-usaha.html

Cnnindonesia.com. (2020). 5 Dampak Omnibus Law Ciptaker bagi Pekerja di Indonesia. Retrieved December 26, 2020, from www.cnnindonesia.com website: https://www.cnnindonesia.com/ekonomi/20201006135421-532-554944/5-dampak-omnibus-lawciptaker-bagi-pekerja-di-indonesia.

CNNIndonesia.com. (2020). 8 Dampak Covid bagi Buruh Versi FSBPI: PHK Hingga Eksploitasi. Retrieved December 26, 2020, from www.cnnindonesia.com website: https://www.cnnindonesia.com/ekonomi/20201219165052-92-584233/8-dampak-covid-bagiburuh-versi-fsbpi-phk-hingga-eksploitasi

De Witte, H. (1999). Job Insecurity and Psychological Well-being: Review of the Literature and Exploration of Some Unresolved Issues. European Journal of Work and Organizational Psychology, 8(2), 155-177. https://doi.org/10.1080/135943299398302

Dole, C., \& Schroeder, R. G. (2001). The impact of various factors on the personality, job satisfaction and turnover intentions of professional accountants. Managerial Auditing Journal, 16(4), 234245. https://doi.org/10.1108/02686900110389188

Edison, E., Anwar, Y., \& Komariyah, I. (2018). Sumber Daya Manusia: Strategi dan Perubahan dalam Rangka Meningkatkan Kinerja Pegawai dan Organisasi. Bandung: ALFABETA.

Fahmy, E., Tura, T. B., \& Sukapti, S. (2021). Pengaruh Motivasi Kerja dan Lingkungan Kerja Terhadap Prestasi Kerja Karyawan Pada PT Screenplay Productions Di Jakarta. Jurnal Ekonomi Efektif, 3(4), 535-545. http://openjournal.unpam.ac.id/index.php/JEE/article/view/11291

Greenhalgh, L., \& Rosenblatt, Z. (1984). Job Insecurity: Toward Conceptual Clarity. Academy of Management Review, 9(3), 438-448. https://doi.org/10.5465/amr.1984.4279673

Halimah, T. N., Fathoni, A., \& Maria M Minarsih. (2016). Pengaruh Job Insecurity, Kepuasan Kerja dan Lingkungan Kerja terhadap Turnover Intention Pramuniaga di Gelael Supermarket ( Studi Kasus pada Gelael Superindo Kota Semarang ). Journal of Management, 2(2), 1524-1540. http://jurnal.unpand.ac.id/index.php/MS/article/view/606/0

Hanaysha, J., \& Tahir, P. R. (2016). Examining the Effects of Employee Empowerment, Teamwork, and Employee Training on Job Satisfaction. Procedia - Social and Behavioral Sciences, 219(May), 272-282. https://doi.org/10.1016/j.sbspro.2016.05.016

Haque, A., Fernando, M., \& Caputi, P. (2019). The Relationship Between Responsible Leadership and Organisational Commitment and the Mediating Effect of Employee Turnover Intentions: An 
Empirical Study with Australian Employees. Journal of Business Ethics, 156(3), 759-774. https://doi.org/10.1007/s10551-017-3575-6

Hellgren, J., Sverke, M., \& Isaksson, K. (1999). A Two-dimensional Approach to Job Insecurity: Consequences for Employee Attitudes and Well-being. European Journal of Work and Organizational Psychology, 8(2), 179-195. https://doi.org/10.1080/135943299398311

Januartha, A. A. G. A., \& Adnyani, I. G. . D. (2019). Pengaruh Job Insecurity dan Kepuasan Kerja terhadap Turnover Intention pada Karyawan Hotel. E-Jurnal Manajemen Universitas Udayana, 8(2), 7548-7575. https://doi.org/10.24843/ejmunud.2019.v08.i02.p01

Joarder, M. H. R., Sharif, M. Y., \& Kawsar, A. (2011). Mediating Role of Affective Commitment in HRM Practices and Turnover Intention Relationship: A Study in a Developing Context. Business and Economics Research Journal, 2(4), 135-158. https://www.berjournal.com/mediating-role-of-affective-commitment-in-hrm-practices-andturnover-intention-relationship-a-study-in-a-developing-context-2

Jung, H. S., Jung, Y. S., \& Yoon, H. H. (2021). COVID-19: The effects of job insecurity on the job engagement and turnover intent of deluxe hotel employees and the moderating role of generational characteristics. International Journal of Hospitality Management, 92, 95-103. https://doi.org/10.1016/j.ijhm.2020.102703

Kartika, G., \& Purba, D. E. (2018). Job Satisfaction and Turnover Intention: The Mediating Effect of Affective Commitment. Psychological Research on Urban Society, 1(2), 100-106. https://doi.org/10.7454/proust.v1i1.21

Koestanto, D., \& Ardi, R. P. (2017). Pengaruh Job Insecurity, Lingkungan Kerja dan Kepuasan Kerja Terhadap Keinginan Berpindah Kerja Karyawan Hotel Grand Candi Semarang. Jurnal Gemawisata, 53(9), 1689-1699. ts.co.id/jurnal/index.php/JT/article/view/70

Kompas.com. (2020). Apa Itu Omnibus Law Cipta Kerja, Isi, dan Dampaknya bagi Buruh?. Retrieved October 21, 2021, from www.kompas.com website: https://www.kompas.com/tren/read/2020/10/06/104500965/apa-itu-omnibus-law-cipta-kerja-isidan-dampaknya-bagi-buruh?page=all

Kreitner, R., \& Angelo, K. (2014). Organizational Behavioral (5th ed.). Boston: McGraw-Hill.

Kristanto, S., Rahyuda, I. K., \& Riana, I. G. (2014). Pengaruh Keadilan Organisasional terhadap Kepuasan Kerja dan Dampaknya terhadap Komitmen, dan Intensi Keluar di PT Indonesia Power UBP Bali. E-Jurnal Ekonomi dan Bisnis Universitas Udayana, 3(6), 308-329. https://ojs.unud.ac.id/index.php/EEB/article/view/6447

Lee, S. H., \& Jeong, D. Y. (2017). Job Insecurity and Turnover Intention: Organizational Commitment as Mediator. Social Behavior and Personality, 45(4), 529-536. https://doi.org/10.2224/sbp.5865

Lumbanrau, R. E. (2020). Omnibus Law: Alasan Buruh Berdemo di Tengah Ancaman Virus Corona 'Covid-19 Berdampak Satu Generasi, Omnibus Law Hingga Tujuh Turunan. Retrieved October 19, 2021, from BBC.com website: https://www.bbc.com/indonesia/indonesia-54382465

Mauno, S., De Cuyper, N., Tolvanen, A., Kinnunen, U., \& Mäkikangas, A. (2014). Occupational Well-Being As A Mediator Between Job Insecurity and Turnover Intention: Findings at the Individual and Work Department Levels. European Journal of Work and Organizational Psychology, 23(3), 381-393. https://doi.org/10.1080/1359432X.2012.752896 
Novi Ali Marzuqi. Pengaruh Job Insecurity, Job Satisfaction, Dan Lingkungan Kerja Terhadap Turnover Intention Karyawan.

Mbah, S. E., \& Ikemefuna, C. O. (2012). Job Satisfaction and Employee s' Turnover Intentions in total Nigeria plc . in Lagos State. International Journal of Humanities and Social Science, 2(14), 275-287. https://www.ijhssnet.com/journal/index/1129

Mobley, W. . (2011). Pergantian Karyawan: Sebab, Akibat dan Pengendaliannya (N. Imam (ed.); Terjemahan). Jakarta: PT Pustaka Binaman Pressindo.

Nikmah, R. M., Heru Sri Wulan, SE, M., \& Adji Seputro, SE, M. (2018). Analysis of the Influence of the Work Environment, Work Stress, Job Satisfaction, and Career Development on Intention Turnover Study on PT. Pearland Boyolali. Journal of Management, 4(4), 1-9. http://jurnal.unpand.ac.id/index.php/MS/article/view/1155

Parwita, G. B. S., Suryani, N. N., \& Adriani, N. K. . (2019). Kepuasan Kerja dan Komitmen Organisasi Pengaruhnya terhadap Turnover Intention. Forum Manajemen, 17(2), 87-96. https://ojs.stimihandayani.ac.id/index.php/FM/article/view/334

Prabawa, M. Y., \& Suwandana, I. G. M. (2017). Pengaruh Ketidakamanan Kerja, Kepuasan Kerja dan Komitmen Organisasional terhadap Turnover Intention pada Grand Mirage Resort \& Thalasso Bali. E-Jurnal Ekonomi dan Bisnis Universitas Udayana, 6(12), 6561-6591. https://ojs.unud.ac.id/index.php/Manajemen/article/view/33921

Priansa, D. . (2018). Perencanaan dan Pengembangan Sumber Daya Manusia. Bandung: ALFABETA.

Putra, I. D. G. D., \& Utama, I. W. M. (2017). Pengaruh Lingkungan Kerja dan Kepuasan Kerja terhadap Tunover Intention di Mayaloka Villas Seminyak. E-Jurnal Manajemen Universitas Udayana, 6(9), 5116-5143. https://ojs.unud.ac.id/index.php/Manajemen/article/view/31993

Putri, E., Ekowati, V. M., Supriyanto, A. S., \& Mukaffi, Z. (2019). The Effect of Work Environment on Through Work Discipline. International Journal Of Research-Granthaalayah, 7(4), 132-140. https://doi.org/10.5281/zenodo.2653144

Putri, E. I. P., \& Irfani, H. A. (2020). Pengaruh Kepuasan Kerja dan Lingkungan Kerja terhadap Turnover Intention di PT. Neuronworks Indonesia. Prosiding Manajemen, 6(2), 802-808. https://doi.org/http://dx.doi.org/10.29313/.v6i2.23059

Qureshi, M. I. (2012). Job Stress, Workload, Environment and Employees Turnover Intentions: Destiny or Choice. Archives Des Sciences, 65(8), 230-241. https://papers.ssrn.com/sol3/papers.cfm?abstract_id=2152930

Rosmaini, R., \& Tanjung, H. (2019). Pengaruh Kompetensi, Motivasi dan Kepuasan Kerja terhadap Kinerja Pegawai. Maneggio: Jurnal Ilmiah Magister Manajemen, 2(1), 1-15. https://doi.org/10.30596/maneggio.v2i1.3366

Saputra, E. G. A., Maryam, S., \& Setya M, F. (2020). Job Insecurity, Job Satisfaction dan Lingkungan Kerja Terhadap Turnover Intention PT. Bima Polyplast Di Sukoharjo. Edunomika, 04(01), 263270. https://jurnal.stie-aas.ac.id/index.php/jie/article/view/926

Sedarmayanti. (2017). Manajemen Sumber Daya Manusia. Bandung: Refika Aditama.

Siagian, T. S., \& Khair, H. (2018). Pengaruh Gaya Kepemimpinan dan Lingkungan Kerja terhadap Kinerja Karyawan dengan Kepuasan Kerja sebagai Variabel Intervening. Maneggio: Jurnal Ilmiah Magister Manajemen, 1(1), 59-70. https://doi.org/10.30596/maneggio.v1i1.2241

Sujarweni, V. W. (2015). Metodologi Penelitian: Lengkap, Praktis dan Mudah Dipahami. 
Yogyakarta: Pustaka Baru Press.

Suprayitno dan Sukir. (2017). Pengaruh Disiplin Kerja, Lingkungan Kerja dan Motivasi Kerja terhadap Kinerja Karyawan. Jurnal Manajemen Sumber Daya Manusia, 2(1), 23-34. http://ejurnal.unisri.ac.id/index.php/Manajemen/article/view/77

Sutrisno, E. (2016). Manajemen Sumber Daya Manusia. Jakarta: Kencana Prenada Media Grup.

Tripathi, P., \& Pandey, M. K. (2017). Examining the Relationship between Work-Family Conflict, Job Satisfaction and Employee's Turnover Intention. Journal of Psychosocial Research, 12(2), 451-459. https://psycnet.apa.org/record/2018-11425-022

Ünsal, B., Çakmak, Ö., \& Witte, H. (2012). Job Insecurity and Affective Commitment in Seasonal Versus Permanent Workers. International Journal of Humanities and Social Science, 2(24), 1420. https://citeseerx.ist.psu.edu/messages/downloadsexceeded

Utama, I. W. B. S., \& Surya, I. B. K. (2020). Peran Komitmen Organisasional Memediasi Pengaruh Kepuasan Kerja terhadap Turnover Intention. E-Jurnal Manajemen Universitas Udayana, 9(8), 3062-3081. https://doi.org/10.24843/ejmunud.2020.v09.i08.p09

Widodo, S. (2015). Manajemen Pengembangan Sumber Daya Manusia. Yogyakarta: Pustaka Pelajar.

Zhang, W., Meng, H., Yang, S., \& Liu, D. (2018). The Influence of Professional Identity, Job Satisfaction, and Work Engagement on Turnover Intention among Township Health Inspectors in China. International Journal of Environmental Research and Public Health, 15(5), 1-13. https://doi.org/10.3390/ijerph15050988 